\title{
Effect of Grain Source and Exogenous Phytase on Phosphorus Digestibility in Dairy Cows
}

\author{
R. L. Kincaid, ${ }^{1}$ D. K. Garikipati, ${ }^{1}$ T. D. Nennich, ${ }^{2}$ and J. H. Harrison ${ }^{2}$ \\ ${ }^{1}$ Animal Sciences Department, Washington State University, Pullman 99164-6310 \\ ${ }^{2}$ Puyallup Research and Extension Center, Washington State University, Puyallup 98371
}

\begin{abstract}
Two experiments were conducted to determine $\mathrm{P}$ digestibility in lactating dairy cows fed corn or barley as grain sources. The first experiment utilized a replicated incomplete $5 \times 4$ Latin square design with 8 lactating Holstein cows fed diets containing either corn alone or corn in combination with one of 4 barley varieties that differed in chemical composition. Total tract digestibility of $\mathrm{P}$ ranged from 11 to $29 \%$ for diets containing the barley varieties and was approximately $35 \%$ for the corn diet. A second experiment compared $\mathrm{P}$ digestibility in cows fed diets containing corn or barley when exogenous phytase was added to the diets. Lactating Holstein cows $(n=16)$ were arranged in 4 replications of a Latin square with 2 grains (barley or corn), fed separately or with added exogenous phytase (427 phytase units $/ \mathrm{kg}$ of total mixed ration and 4 periods of $21 \mathrm{~d}$. Phytate $\mathrm{P}$ comprised about $50 \%$ of the total $\mathrm{P}(0.46 \% \mathrm{P})$ in the total mixed ration. The concentration of serum inorganic $\mathrm{P}$ was higher in cows fed diets with exogenous phytase ( 5.8 vs. $6.5 \mathrm{mg} / \mathrm{dL}$ in cows fed barley diets and $5.5 \mathrm{vs}$ $6.0 \mathrm{mg} / \mathrm{dL}$ in cows fed corn diets). Using acid detergent lignin as an internal marker, hydrolysis of phytate $\mathrm{P}$ was increased by the exogenous phytase, and total $\mathrm{P}$ digestibility tended to be increased. In contrast to Experiment 1, in Experiment 2 there was no effect of grain source on P digestibility and total fecal P. Dry matter intake and efficiency of milk production were not affected by exogenous phytase or grain type. Although phytase activity occurs in the rumen, physical properties of the diet and ruminal passage rates may prevent total hydrolysis of phytate in the rumen of lactating cows. Thus, exogenous dietary phytase might improve $\mathrm{P}$ digestibility in dairy cows in some dietary situations.
\end{abstract} (Key words: phosphorus, phytate, phytase, cattle)

\section{INTRODUCTION}

Although $\mathrm{P}$ has more known functions in the body than any other mineral nutrient (Lynch and Caffrey,

Received October 15, 2004.

Accepted April 29, 2005.

Corresponding author: R. L. Kincaid, e-mail: rkincaid@wsu.edu.
1997), it is one of the main polluting nutrients from animal agriculture. Accordingly, nutrient management plans for concentrated animal feeding operations must consider a whole farm P budget (EPA, 2002). Dietary $\mathrm{P}$ management is a key strategy in reducing $\mathrm{P}$ accumulation in dairy farms (Valk et al., 2000). Therefore, methods to increase P digestibility in cattle and to reduce $\mathrm{P}$ excretion are needed.

In general, digestibility of $\mathrm{P}$ in cereal grains and their by-products is lower than the digestibility of $\mathrm{P}$ in commonly used inorganic supplements (NRC, 2001). In cereal grains, phytic acid (myo-inositol 1,2,3,4,5,6 hexakisphosphate) typically represents 65 to $85 \%$ of total $\mathrm{P}$ (Reddy et al., 1982). Salts of phytic acid are deposited in the aleurone, scutellum, cotyledon, and endosperm during seed formation (Bergman et al., 2000). Phytates in cereals are not uniformly distributed within the kernel but are associated with specific morphological components in the seeds (Ravindran, 1999). Corn has $88 \%$ of its phytic acid distributed in the germ layer in contrast to barley, which has $87 \%$ of its phytic acid in the aleurone and only 13\% in the germ (O'Dell et al., 1972). Whereas corn contains little phytase activity (Eeckhout and de Paepe, 1994), barley contains considerable endogenous phytase, chiefly around the protein bodies in the aleurone layer (Tronier et al., 1971).

Although phytate often is presumed completely hydrolyzed prior to fecal excretion, ruminal hydrolysis is not uniform among feedstuffs and is affected by factors such as processing methods (Bravo et al., 2000). In addition, high dietary Ca reduces the effectiveness of ruminal phytase activity (Sansinena, 1999). Thus, phytate hydrolysis is not complete within the rumen, and phytate has been shown to be present in feces of cattle fed a barley-based diet (Taylor et al., 2001).

Ruminal phytase is largely of bacterial origin and is associated with the bacterial cell pellet (Yanke et al., 1998). Grain type, processing methods, and ruminal outflow rates may affect the ability of phytases in the rumen to access and completely hydrolyze phytate in grains. Exogenous phytase, by increasing total phytase activity in the fluid portion of ruminal contents, might increase the extent of ruminal hydrolysis of phytate. 
Table 1. Ingredient composition of TMR fed to lactating cows (Experiment 1, $\mathrm{n}=8$ ).

\begin{tabular}{|c|c|c|c|c|c|}
\hline & \multicolumn{5}{|c|}{ Dietary treatment and barley variety } \\
\hline & Corn & Baroness & Idagold & Steptoe & Harrington \\
\hline Alfalfa hay, \% & 19.3 & 19.1 & 19.1 & 19.1 & 19.1 \\
\hline Grass silage, \% & 22.7 & 22.7 & 22.7 & 22.7 & 22.7 \\
\hline Whole cottonseed, \% & 7.7 & 7.6 & 7.6 & 7.6 & 7.6 \\
\hline Corn distillers grains, $\%$ & 4.9 & 5.9 & 5.9 & 5.9 & 5.9 \\
\hline Corn, cracked, \% & 38.4 & 13.3 & 13.3 & 13.3 & 13.3 \\
\hline Barley, ${ }^{1}$ steam rolled, \% & - & 24.3 & 24.3 & 24.3 & 24.3 \\
\hline Soybean meal, \% & 0.77 & 0.76 & 0.76 & 0.76 & 0.76 \\
\hline Blood meal, \% & 0.71 & 0.70 & 0.70 & 0.70 & 0.70 \\
\hline Fish meal, $\%$ & 0.79 & 0.79 & 0.79 & 0.79 & 0.79 \\
\hline Megalac, ${ }^{2} \%$ & 0.21 & 0.62 & 0.62 & 0.62 & 0.62 \\
\hline Urea, \% & 1.01 & 0.76 & 0.76 & 0.76 & 0.76 \\
\hline Sodium bicarbonate, $\%$ & 0.75 & 0.74 & 0.74 & 0.74 & 0.74 \\
\hline Limestone, \% & 0.43 & 0.42 & 0.42 & 0.42 & 0.42 \\
\hline Dicalcium phosphate, $\%$ & 0.52 & 0.51 & 0.51 & 0.51 & 0.51 \\
\hline Mineral, ${ }^{3} \%$ & 1.10 & 1.08 & 1.08 & 1.08 & 1.08 \\
\hline $\mathrm{MgO}, \%$ & 0.24 & 0.23 & 0.23 & 0.23 & 0.23 \\
\hline Bloat guard, \% & 0.06 & 0.06 & 0.06 & 0.06 & 0.06 \\
\hline Vitamin premix ${ }^{4}, \%$ & 0.39 & 0.38 & 0.38 & 0.38 & 0.38 \\
\hline \\
\hline & & & & \multicolumn{2}{|c|}{${ }^{2}$ Church \& Dwight Co., Inc., Princeton, NJ. } \\
\hline \multicolumn{6}{|c|}{$\begin{array}{l}{ }^{3} \mathrm{Mineral} \mathrm{premix} \mathrm{contained} \mathrm{approximately} 30 \% \mathrm{Na}, 43 \% \mathrm{Cl}, 12 \mathrm{mg} / \mathrm{kg} \text { of } \mathrm{Co}, 720 \mathrm{mg} / \mathrm{kg} \text { of Cu, } 25 \mathrm{mg} / \mathrm{kg} \\
\text { of Fe, } 70 \mathrm{mg} / \mathrm{kg} \text { of I , } 2350 \mathrm{mg} / \mathrm{kg} \text { of } \mathrm{Mn}, 37 \mathrm{mg} / \mathrm{kg} \text { of Se, and } 1740 \mathrm{mg} / \mathrm{kg} \text { of } \mathrm{Zn} \text {. }\end{array}$} \\
\hline \multicolumn{6}{|c|}{$\begin{array}{l}{ }^{4} \text { Vitamin premix contained approximately } 2,100,000 \mathrm{IU} / \mathrm{kg} \text { of vitamin } \mathrm{A}, 400,000 \mathrm{IU} / \mathrm{kg} \text { of vitamin } \mathrm{D} \text {, and } \\
7550 \mathrm{IU} / \mathrm{kg} \text { of vitamin } \mathrm{E} \text {. }\end{array}$} \\
\hline
\end{tabular}

Therefore, 2 experiments were conducted on $\mathrm{P}$ digestion in lactating cows. The first experiment compared the $\mathrm{P}$ digestibility of corn and 4 varieties of barley. The second experiment determined whether exogenous phytase increases $\mathrm{P}$ digestibility of lactating cows fed concentrates containing either corn or barley.

\section{MATERIALS AND METHODS}

The protocols were approved by the Institutional Animal Care and Use Commmittee of Washington State University.

\section{Experiment 1}

Lactating multiparous Holstein cows ( $\mathrm{n}=8$; multiparous), averaging $174 \mathrm{DIM}$ at the start of the trial, were used in a double incomplete $5 \times 4$ Latin square design to evaluate $\mathrm{P}$ digestibility when corn was partially replaced with one of 4 varieties of steam-rolled barley (Baroness, Idagold, Harrington, and Steptoe) in diets. Each experimental period was $14 \mathrm{~d}$. The first $10 \mathrm{~d}$ served as an adjustment period followed by $4 \mathrm{~d}$ of sample collection. Cows were housed in a tie-stall barn and were individually fed their treatment diets as a TMR once per day. Total mixed rations and orts were sampled on a daily basis, subsampled, and composited on a weight basis over the 4-d collection period. The ingredient and chemical compositions of the diets are described in Tables 1 and 2. Grass silage and alfalfa hay were included as the main forages; therefore, grains were the primary sources of starch. Some cracked corn was included in all of the diets, and the diets with the test barley varieties contained $24.3 \%$ steam-rolled barley. Dry matter intake, orts, and milk yield $(2 \times$ milking schedule) were recorded daily. Total feces were collected and subsampled on a daily basis for 4 consecutive $d$, and subsamples were combined to obtain a sample for each treatment period.

\section{Experiment 2}

Lactating multiparous Holstein cows $(\mathrm{n}=16)$ were arranged in 4 replicates of a $4 \times 4$ Latin square design with 4 dietary treatments and 4 periods. Treatment periods were $28 \mathrm{~d}$. The first $21 \mathrm{~d}$ served as an adaptation period, and the final $7 \mathrm{~d}$ were for data collection. The dietary treatments were 26\% barley (Baroness) with no added phytase (barley); 26\% barley plus 427 FTU of phytase/kg of TMR on a DM basis (barley + phytase); $26 \%$ corn with no added phytase (corn); and $26 \%$ corn plus 427 FTU of phytase/kg of TMR on a DM basis (corn + phytase). One FTU is the amount of enzyme that liberates $1 \mu \mathrm{mol}$ of phosphate/min from $0.0051 \mathrm{~mol} / \mathrm{L}$ of $\mathrm{Na}$ phosphate at $37^{\circ} \mathrm{C}$ and $\mathrm{pH}$ 5.5. All diets contained approximately $0.46 \% \mathrm{P}, 18 \% \mathrm{CP}, 35 \% \mathrm{NDF}$, and $19 \%$ $\mathrm{ADF}$. Ingredient and nutrient compositions of the diets are given in Tables 3 and 4. The diets were fed as TMR. Of the barley or corn that was added to the diets, about 
Table 2. Chemical composition of TMR fed to lactating cows (experiment 1).

\begin{tabular}{llcccc}
\hline & \multicolumn{5}{c}{ Dietary treatment and barley variety } \\
\cline { 2 - 5 } & Corn & Baroness & Idagold & Steptoe & Harrington \\
\hline $\mathrm{CP}, \%$ & $20.2(0.56)^{1}$ & $20.9(0.86)$ & $19.8(0.30)$ & $20.4(1.14)$ & $21.3(0.71)$ \\
$\mathrm{NDF}, \%$ & $38.0(1.69)$ & $40.6(1.85)$ & $40.1(1.04)$ & $41.5(1.72)$ & $41.7(1.43)$ \\
$\mathrm{ADF}, \%$ & $21.6(0.67)$ & $23.0(1.23)$ & $22.5(2.0)$ & $23.6(1.98)$ & $23.7(1.53)$ \\
$\mathrm{Ca} \%$ & $1.04(0.08)$ & $1.16(0.09)$ & $1.13(0.12)$ & $1.17(0.08)$ & $1.07(0.13)$ \\
P,\% & $0.58(0.01)$ & $0.55(0.02)$ & $0.50(0.04)$ & $0.57(0.02)$ & $0.54(0.04)$ \\
Phytate P, \% & $0.18(0.02)$ & $0.20(0.01)$ & $0.19(0.02)$ & $0.15(0.02)$ & $0.20(0.02)$ \\
\hline
\end{tabular}

${ }^{1}$ Standard deviations are presented in parentheses.

$60 \%$ was steam-rolled and $40 \%$ was ground and pelleted with other ingredients. The phytase was added to the pelleted portion of the concentrate mix.

At the start of the experiment, cows averaged $210 \pm$ 19 DIM and had a mean BW of $702 \pm 79 \mathrm{~kg}$. The cows were randomly assigned to one of 4 dietary treatment groups ( 4 cows per treatment per period). The cows were fed individually via Calan gates and had access to water and feed. Cows were switched to a different treatment diet at the end of each period until each cow had received all 4 treatment diets.

Cows were milked twice daily, and milk yield was recorded at each milking. Body weights were recorded initially and on d 21 of each study period. The amount of diet offered and orts were recorded daily to calculate feed intake. Samples of TMR were collected weekly and

Table 3. Ingredient composition of TMR fed to lactating cows containing barley or corn, with or without added phytase (experiment 2).

\begin{tabular}{|c|c|c|c|c|}
\hline & \multicolumn{4}{|c|}{ Dietary treatments } \\
\hline & Barley & $\begin{array}{l}\text { Barley }+ \\
\text { phytase }^{1}\end{array}$ & Corn & $\begin{array}{l}\text { Corn }+ \\
\text { phytase }^{2}\end{array}$ \\
\hline Alfalfa haylage, $\%$ & 25.6 & 25.6 & 25.6 & 25.6 \\
\hline Alfalfa hay, $\%$ & 22.3 & 22.3 & 22.3 & 22.3 \\
\hline Barley, steam rolled, \% & 15.1 & 15.1 & - & - \\
\hline Barley, pelleted, \% & 10.7 & 10.7 & - & - \\
\hline Corn, steam rolled, $\%$ & - & - & 15.1 & 15.1 \\
\hline Corn, pelleted, \% & - & - & 10.7 & 10.7 \\
\hline Whole cottonseed, \% & 9.9 & 9.9 & 9.9 & 9.9 \\
\hline Wheat millrun, \% & 6.6 & 6.6 & 6.6 & 6.6 \\
\hline Peas, culled, \% & 5.3 & 5.3 & 5.3 & 5.3 \\
\hline Soybean meal, \% & 1.6 & 1.6 & 1.6 & 1.6 \\
\hline Sodium carbonate, $\%$ & 0.71 & 0.71 & 0.71 & 0.71 \\
\hline Limestone, \% & 0.53 & 0.53 & 0.53 & 0.53 \\
\hline Trace mineral premix,${ }^{3} \%$ & 0.53 & 0.53 & 0.53 & 0.53 \\
\hline $\mathrm{MgO}, \%$ & 0.14 & 0.14 & 0.14 & 0.14 \\
\hline Molasses, \% & 0.89 & 0.89 & 0.89 & 0.89 \\
\hline Vitamin A premix, ${ }^{4} \%$ & 0.018 & 0.018 & 0.018 & 0.018 \\
\hline Vitamin D premix, ${ }^{5} \%$ & 0.018 & 0.018 & 0.018 & 0.018 \\
\hline Vitamin E premix, ${ }^{6} \%$ & 0.0036 & 0.0036 & 0.0036 & 0.0036 \\
\hline 4 -plex, ${ }^{7} \%$ & 0.035 & 0.035 & 0.035 & 0.035 \\
\hline Pellet binder, \% & 0.018 & 0.018 & 0.018 & 0.018 \\
\hline Phytase, ${ }^{8} \%$ & - & 0.09 & - & 0.09 \\
\hline \multicolumn{5}{|c|}{$\begin{array}{l}{ }^{1} \text { Barley }+427 \mathrm{FTU} \text { phytase } / \mathrm{kg} \text { of DM. One FTU is the amount of enzyme that liberates } 1 \mu \mathrm{mol} \text { of phosphate/ } \\
\text { min from } 0.0051 \mathrm{~mol} / \mathrm{L} \text { of } \mathrm{Na} \text { phosphate at } 37^{\circ} \mathrm{C} \text { and } \mathrm{pH} 5.5 \text {. }\end{array}$} \\
\hline \multicolumn{5}{|c|}{${ }^{2}$ Corn +427 FTU phytase/kg of DM. } \\
\hline \multicolumn{5}{|l|}{$\begin{array}{l}{ }^{3} \text { Consists o } \\
0.009 \% \text { Se. }\end{array}$} \\
\hline \multicolumn{5}{|l|}{${ }^{4}$ Consists of $30,000 \mathrm{IU} / \mathrm{g}$. } \\
\hline \multicolumn{5}{|l|}{${ }^{5}$ Consists of $8810 \mathrm{IU} / \mathrm{g}$. } \\
\hline \multicolumn{5}{|l|}{${ }^{6}$ Consists of $500 \mathrm{IU} / \mathrm{g}}$. \\
\hline \multirow{2}{*}{\multicolumn{5}{|c|}{$\begin{array}{l}{ }^{7} \text { Contains } 2.58 \% \mathrm{Zn} \text { as } \mathrm{Zn} \mathrm{Met}, 1.43 \% \mathrm{Mn} \text { as } \mathrm{Mn} \mathrm{Met}, 0.9 \% \mathrm{Cu} \text { as } \mathrm{Cu} \text { Lys, and } 0.18 \% \text { Co as Co glucoheptonate. } \\
\text { Zinpro Corp., Eden Prairie, MN. }\end{array}$}} \\
\hline & & & & \\
\hline \multicolumn{5}{|c|}{$\begin{array}{l}{ }^{8} \text { Phytase (Aspergillus niger) } 600 \text { PAK manufactured (ADM Animal Health \& Nutrition Division, Des } \\
\text { Moines, IA). Contains } 600 \text { FTU/g. }\end{array}$} \\
\hline
\end{tabular}


Table 4. Chemical composition of TMR for lactating cows (experiment 2).

\begin{tabular}{lllllll}
\hline & \multicolumn{5}{c}{ Dietary Treatment } \\
\cline { 2 - 7 } & Barley & $\begin{array}{l}\text { Barley }+ \\
\text { phytase }^{1}\end{array}$ & Corn & $\begin{array}{l}\text { Corn }+ \\
\text { phytase }^{2}\end{array}$ & SE & $P<$ \\
\hline CP, \% & 18.0 & 18.1 & 18.2 & 18.2 & 0.18 & 0.70 \\
NDF, \% & 34.9 & 34.7 & 34.8 & 35.1 & 0.30 & 0.48 \\
ADF, \% & 19.4 & 19.1 & 19.6 & 18.9 & 0.55 & 0.30 \\
Ca, \% & 1.16 & 1.14 & 1.11 & 1.18 & 0.04 & 0.39 \\
P, \% & 0.45 & 0.47 & 0.46 & 0.45 & 0.15 & 0.42 \\
Phytate P, \% & 0.235 & 0.237 & 0.236 & 0.238 & 0.02 & 0.17 \\
ADL, \% & 3.20 & 3.14 & 3.30 & 3.36 & 0.24 & 0.42 \\
\hline
\end{tabular}

\footnotetext{
${ }^{1}$ Barley $+427 \mathrm{FTU}$ phytase/kg of DM. One FTU is the amount of enzyme that liberates $1 \mu$ mol of phosphate/ min from $0.0051 \mathrm{~mol} / \mathrm{L}$ of $\mathrm{Na}$ phosphate at $37^{\circ} \mathrm{C}$ and $\mathrm{pH} 5.5$.

${ }^{2}$ Corn + 427 FTU phytase/kg of DM.
}

composited (wt/wt) by each period for each treatment. Approximately 90 min after the a.m. feeding, blood samples were collected from the coccygeal vein into nonheparinized vacutainers. Serum was harvested after centrifugation at $3000 \times g$ for $20 \mathrm{~min}$ and stored at $-20^{\circ} \mathrm{C}$ until further analysis. Milk samples were collected in plastic bottles and immediately taken to the laboratory where they were frozen until further analysis. Subsamples of milk also were sent to the regional DHIA laboratory (Burlington, WA) for analysis of major components. Fecal samples (approximately $150 \mathrm{~g}$ ) were collected from the rectum of cows during one sample collection that took place at $0900 \mathrm{~h}$. Fecal samples were placed into plastic cups, sealed immediately, and taken to the laboratory where they were dried at $60^{\circ} \mathrm{C}$ in a forced-air oven and stored until further analysis.

Analyses. Composite feed and fecal samples were dried $\left(60^{\circ} \mathrm{C}\right.$ for $\left.48 \mathrm{~h}\right)$ and ground to pass a $1-\mathrm{mm}$ screen (Wiley mill; Arthur H. Thomas Co., Philadelphia, PA). A subsample of ground feed and feces were dried at $100^{\circ} \mathrm{C}$ for $24 \mathrm{~h}$ for calculation of absolute DM. Samples of feed and feces were analyzed in duplicate for CP, NDF, ADF, ADL, Ca, P, and phytate P. Blood and milk samples were analyzed for $\mathrm{Ca}$ and $\mathrm{P}$. Crude protein was determined using a Leco 528 Protein Analyzer (AOAC, 1995), NDF and ADF were determined using an Ankom Fiber analyzer (Ankom Technology, Macedon, NY; AOAC, 1995), and ADL was analyzed according to the AOAC (2001). Concentrations of ADL in the TMR and feces were used to estimate $\mathrm{P}$ digestibility and fecal output. Calcium was determined by atomic absorption spectrophotometry (Robinson, 1975), and P was determined by colorimetry (AOAC, 2001). Concentrations of phytate $\mathrm{P}$ in feed and fecal samples were determined by the ferric precipitation method (Raboy et al., 1984).

\section{Statistical Analyses}

Experiment 1. Statistical analysis was done using PROC MIXED of SAS (2001). The statistical model was a double incomplete Latin square with 5 treatments and 4 periods. The statistical model used to analyze the data was

$$
Y_{i k j}=\mu+\alpha_{i}+b_{j}+c_{k}+e_{i j k}
$$

where

$$
\begin{aligned}
Y_{i k j} & =\text { observed response } \\
\mu & =\text { overall mean } \\
\alpha_{i} & =\text { fixed effect of treatment } \\
b_{j} & =\text { random effect of cow } \\
c_{k} & =\text { random effect of period, and } \\
e_{i j k} & =\text { residual error }
\end{aligned}
$$

Results are reported as least squares means. A protected LSD test was used to separate treatment means. Differences between observations were considered significant at $P<0.05$.

Experiment 2. Data were analyzed by PROC GLM of SAS (2001). The statistical model used was

$$
Y_{i j k l}=\mu+\alpha_{i}+\beta_{j}+(\alpha \times \beta)_{i j}+\gamma_{k}+\rho_{l}+e_{i j k l}
$$

where

$$
\begin{aligned}
Y_{i j k l}= & \text { observed response, } \\
\mu= & \text { overall mean, } \\
\alpha_{i}= & \text { fixed effect of grain source (barley or corn), } \\
\beta_{j}= & \text { fixed effect of enzyme treatment (no phy- } \\
& \text { tase or added phytase) } \\
(\alpha \times \beta)_{i j}= & \text { effect of interaction between grain and en- } \\
& \text { zyme treatments, } \\
\gamma_{k}= & \text { fixed effect caused by period, } \\
\rho_{l}= & \text { fixed effect caused by cows in the group, } \\
& \text { and } \\
e_{i j k l}= & \text { residual error. }
\end{aligned}
$$

Significance was declared at $P<0.05$, and trends were declared at $P<0.10$. 
Table 5. Chemical composition of barley varieties fed to lactating cows (experiment 1 ).

\begin{tabular}{lcccc}
\hline & \multicolumn{4}{c}{ Barley variety } \\
\cline { 2 - 5 } & Baroness & Idagold & Steptoe & Harrington \\
\hline $\mathrm{CP}, \%$ & 13.1 & 12.5 & 11.5 & 12.4 \\
$\mathrm{NDF}, \%$ & 28.1 & 30.0 & 33.5 & 30.4 \\
$\mathrm{ADF}, \%$ & 8.4 & 6.9 & 12.4 & 8.7 \\
Starch, \% & 47.9 & 46.2 & 45.6 & 46.9 \\
$\mathrm{Ca} \%$ & 0.05 & 0.05 & 0.06 & 0.06 \\
$\mathrm{P}, \%$ & 0.43 & 0.42 & 0.39 & 0.45 \\
\hline
\end{tabular}

\section{RESULTS AND DISCUSSION}

\section{Experiment 1}

The 4 barley varieties differed in their chemical composition; Baroness contained the highest $\mathrm{CP}$ content, and Steptoe contained the highest fiber content (Table $5)$. The $P$ concentration in the barley varieties ranged from $0.39 \%$ (Steptoe) to $0.45 \%$ (Harrington). This difference in the chemical composition of the barley varieties contributed to the variation in the chemical composition of the TMR, which ranged from 20 to $21 \% \mathrm{CP}, 38$ to $42 \% \mathrm{NDF}, 21.6$ to $23.7 \% \mathrm{ADF}$, and 0.50 to $0.58 \% \mathrm{P}$ (Table 2). The high dietary $\mathrm{P}$ resulted from inclusion of several high $\mathrm{P}$ feedstuffs (corn distillers grains, fish meal, and dicalcium phosphate), which are typically included in diets on commercial dairies in western Washington. Phytate P ranged from 26 to $38 \%$ of total dietary $\mathrm{P}$; the lowest percentage of phytate $\mathrm{P}$ was found in the TMR containing Steptoe barley, and the highest percentage was observed in the TMR containing the Idagold barley.

Dry matter intake, BW, milk yield, and milk composition were unaffected by grain type and barley variety in the diet (Table 6). However, P intake, fecal output of $\mathrm{P}$, and apparent total tract digestibility of $\mathrm{P}$ were affected by the variety of barley that was included in the TMR (Table 7). Total tract $\mathrm{P}$ digestibility in lactating Holstein cows ranged from 11 to $28 \%$ for diets containing one of the 4 barley varieties and was about $37 \%$ for corn. Cows fed the Steptoe barley variety, which had the smallest percentage of phytate $\mathrm{P}$ of all barleys (Table 2), had substantially greater total tract $P$ digestibility than did cows fed the Baroness and Idagold varieties. Accordingly, fecal excretion of $\mathrm{P}$ was less when cows were fed corn compared with barley and was less for the Harrington barley than for the Baroness barley (Table 7). Although the $\mathrm{P}$ concentration in the TMR ranged from 0.50 to $0.58 \%$, the high dietary concentration of $\mathrm{P}$ in study 1 did not appear to depress $\mathrm{P}$ digestibility measurably.

\section{Experiment 2}

The treatment TMR differed only in their content of corn, barley, and added phytase (Table 4). The mean concentration of dietary $\mathrm{P}$ was $0.46 \%$, which, although greater than the minimum $P$ recommended by the NRC (2001), is representative of many diets containing commonly used by-product feeds. The TMR ingredients, including whole cottonseeds, wheat mill run, culled peas, and soybean meal, contributed to the comparatively high dietary $\mathrm{P}$. Of the total amount of $\mathrm{P}$ in the TMR, 26\% of the P was supplied by the corn or barley. Barley had slightly more phytate $P$ than corn $(0.22$ vs. $0.20 \%$ ), and the phytate in barley and corn is distributed differently within the kernel (O'Dell et al., 1972).

There were no treatment effects on DMI, milk yield, and milk composition of cows (Table 8). Although differences in DMI and milk yield in cows fed diets containing either corn or barley have been reported (Casper and Schingoethe, 1989; Yang et al., 1997), generally, differences occur only when the cereal grains constitute 50\% of the diet (Kincaid and Harrison, 2002). The more extensive ruminal starch digestibility of barley than of corn (77 vs. 55\%; McCarthy et al., 1989) can lead to higher concentrations of lactic acid in the rumen (Tamminga et al., 1990). In experiment 2 , cereal grain was only $26 \%$ of the TMR, and the NDF content was relatively high (35\%), which minimized possible differences in ruminal VFA concentrations between the corn and

Table 6. Dry matter intake, BW and milk yield of cows fed corn or known variety of barley in TMR (experiment 1).

\begin{tabular}{|c|c|c|c|c|c|c|c|}
\hline \multirow[b]{2}{*}{ Item } & \multicolumn{5}{|c|}{ Dietary treatment and barley variety } & \multirow[b]{2}{*}{$\mathrm{SE}$} & \multirow[b]{2}{*}{$P^{1}<$} \\
\hline & Corn & Baroness & Idagold & Steptoe & Harrington & & \\
\hline $\mathrm{BW}, \mathrm{kg}$ & 597.1 & 606.4 & 610.1 & 601.8 & 614.8 & 27.2 & 0.42 \\
\hline DMI, kg/d & 19.2 & 19.5 & 19.4 & 19.4 & 18.6 & 1.2 & 0.69 \\
\hline Milk yield, $\mathrm{kg} / \mathrm{d}$ & 19.5 & 20.1 & 21.2 & 20.6 & 21.0 & 3.3 & 0.47 \\
\hline Milk fat, $\%$ & 4.19 & 3.85 & 4.17 & 3.84 & 3.98 & 0.25 & 0.69 \\
\hline Milk CP, ${ }^{2} \%$ & 3.33 & 3.34 & 3.54 & 3.50 & 3.37 & 0.17 & 0.09 \\
\hline
\end{tabular}

${ }^{1}$ Probability of $F$ ratio from ANOVA.

${ }^{2}$ Milk protein values are reported as a percentage of CP in milk. 
Table 7. Intake, fecal output, and digestibility of $\mathrm{P}$ for lactating cows fed diets containing corn or known barley variety (experiment 1 ).

\begin{tabular}{|c|c|c|c|c|c|c|c|}
\hline \multirow[b]{2}{*}{ Item } & \multicolumn{5}{|c|}{ Dietary treatment and barley variety } & \multirow[b]{2}{*}{$\mathrm{SE}^{1}$} & \multirow[b]{2}{*}{$P<$} \\
\hline & Corn & Baroness & Idagold & Steptoe & Harrington & & \\
\hline $\mathrm{P}$ intake, $\mathrm{g} / \mathrm{d}$ & $117^{\mathrm{a}}$ & $107^{\mathrm{bc}}$ & $98^{\mathrm{d}}$ & $111^{\mathrm{ab}}$ & $103^{\mathrm{cd}}$ & 6.6 & 0.01 \\
\hline Fecal $P, g / d$ & $70^{\mathrm{c}}$ & $87^{\mathrm{a}}$ & $84^{\mathrm{ab}}$ & $81^{\mathrm{ab}}$ & $77^{\mathrm{bc}}$ & 7.0 & 0.01 \\
\hline $\mathrm{P}$ digestibility, \% & $34.9^{\mathrm{a}}$ & $19.5^{\mathrm{cd}}$ & $11.4^{\mathrm{d}}$ & $28.3^{\mathrm{ab}}$ & $21.2^{\mathrm{bc}}$ & 4.52 & 0.01 \\
\hline
\end{tabular}

barley treatments. Body weights of the cattle did not differ among treatments (Table 8). The initial mean BW of the cattle was $702 \pm 79 \mathrm{~kg}$, and the final BW was $706 \pm 77 \mathrm{~kg}$.

Milk production efficiency, expressed as milk yield per kilogram of DMI, was unaffected by the dietary treatments (Table 8). A similar result was reported by Yang et al. (1997), who compared barley-, hull-less barley-, and corn-based diets of multiparous lactating dairy cattle and found no difference in efficiency of milk production. However, in primiparous cows, they found a higher ratio of milk yield to digestible DM when those cows were fed hull-less barley as the grain source vs. corn or barley.

Concentrations of $P$ and $C a$ in milk. The percentage of $\mathrm{P}$ in milk was $0.09 \%$ and was not affected by dietary treatment (Table 8). The percentage of $\mathrm{P}$ in milk is primarily a function of milk protein percentage and is not affected by dietary P level (Forar et al., 1982; NRC, 2001). Similarly, the percentage of Ca in milk was $0.13 \%$, and there was no effect of dietary treatment (Table 8).
Concentrations of inorganic $P$ and $C a$ in serum. The addition of exogenous phytase to the diets increased serum inorganic $\mathrm{P}$ in cows fed both the diets containing barley (5.8 vs. $6.6 \mathrm{mg} / \mathrm{dL}$ ) and corn (5.5 vs. $6.0 \mathrm{mg} / \mathrm{dL}$; Figure 1). Plasma inorganic $\mathrm{P}$ is known to fluctuate diurnally in cows and peaks at about $2 \mathrm{~h}$ postfeeding (Forar et al., 1982). In study 2, blood samples were taken about 90 min after feeding, which might have maximized the likelihood of detecting differences among treatments in serum inorganic $P$. There was no difference in serum inorganic $\mathrm{P}$ between cows fed corn or barley as the grain source. Because blood inorganic $\mathrm{P}$ is affected by dietary $\mathrm{P}$ intake (Read et al., 1986), the addition of phytase to the diets apparently increased the amount of absorbable $\mathrm{P}$ in the small intestine of the cows.

In contrast to $\mathrm{P}$, the concentrations of $\mathrm{Ca}$ in serum were not affected either by the exogenous phytase or by the grain source. The serum Ca levels for the barley, barley + phytase, corn, and corn + phytase diets were 9.5, 10.0, 9.6, and $10.1 \mathrm{mg} / \mathrm{dL}$, respectively, and were

Table 8. Effect of grain type and added phytase on BW, feed intake, and milk yield/kg feed intake (DM basis; experiment 2).

\begin{tabular}{|c|c|c|c|c|c|c|c|c|}
\hline & \multicolumn{4}{|c|}{ Dietary treatment } & \multirow[b]{3}{*}{ SE } & \multirow{2}{*}{\multicolumn{3}{|c|}{$P<$}} \\
\hline & & Barley + & & Corn + & & & & \\
\hline & Barley & phytase $^{1}$ & Corn & phytase $^{2}$ & & Grain & Phytase & $\mathrm{G} \times \mathrm{P}^{3}$ \\
\hline $\mathrm{BW}, \mathrm{kg}$ & 704.4 & 699.5 & 702.7 & 705.9 & 79.0 & 0.69 & 0.62 & 0.15 \\
\hline DMI, kg & 28.3 & 28.8 & 29.0 & 28.2 & 0.88 & 0.45 & 0.35 & 0.24 \\
\hline Milk yield, kg/d & 44.5 & 43.5 & 43.5 & 43.0 & 4.5 & 0.29 & 0.25 & 0.57 \\
\hline $4 \%$ FCM, kg/d & 40.1 & 40.2 & 39.6 & 39.0 & 4.7 & 0.39 & 0.40 & 0.64 \\
\hline Milk protein, ${ }^{4} \%$ & 3.05 & 3.08 & 3.03 & 3.09 & 0.01 & 0.91 & 0.13 & 0.73 \\
\hline Milk fat, $\%$ & 3.35 & 3.51 & 3.40 & 3.38 & 0.09 & 0.92 & 0.88 & 0.70 \\
\hline Milk Ca, \% & 0.13 & 0.13 & 0.13 & 0.13 & 0.01 & 0.84 & 0.80 & 0.92 \\
\hline Milk P, \% & 0.09 & 0.09 & 0.09 & 0.09 & 0.008 & 0.89 & 0.89 & 0.88 \\
\hline $\mathrm{PE}^{5}$ & 1.6 & 1.5 & 1.5 & 1.5 & 0.11 & 0.26 & 0.50 & 0.69 \\
\hline
\end{tabular}

\footnotetext{
${ }^{1}$ Barley $+427 \mathrm{FTU}$ phytase $/ \mathrm{kg}$ of DM. One FTU is the amount of enzyme that liberates $1 \mu \mathrm{mol}$ of phosphate/ min from $0.0051 \mathrm{~mol} / \mathrm{L}$ of $\mathrm{Na}$ phosphate at $37^{\circ} \mathrm{C}$ and $\mathrm{pH} 5.5$.

${ }^{2}$ Corn +427 FTU phytase/kg of DM.

${ }^{3} \mathrm{G} \times \mathrm{P}$ is the response caused by grain and phytase interaction.

${ }^{4}$ Milk protein values are reported as the percentage of true protein in milk.

${ }^{5} \mathrm{PE}=$ Milk production efficiency, calculated as $\mathrm{kg}$ of milk/kg feed intake (DM basis).
} 


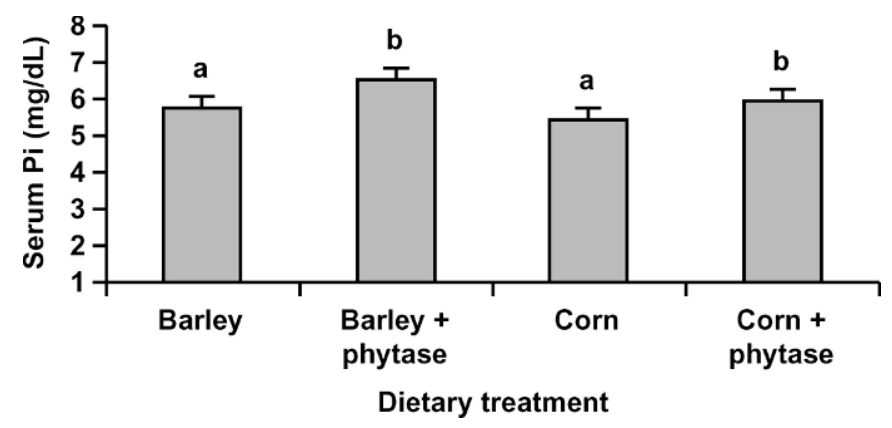

Figure 1. Effect of exogenous dietary phytase on serum inorganic $\mathrm{P}(\mathrm{Pi})$ in lactating cows fed TMR containing either barley or corn. Treatments with different letters differ $(P<0.05$; mean $\mathrm{SE}=0.227)$. Diets with added phytase contained 427 FTU phytase/kg of DM (experiment 2). One FTU is the amount of enzyme that liberates $1 \mu \mathrm{mol}$ of phosphate/min from $0.0051 \mathrm{~mol} / \mathrm{L}$ of $\mathrm{Na}$ phosphate at $37^{\circ} \mathrm{C}$ and $\mathrm{pH}$ 5.5.

within the normal physiological range for cattle (NRC, 2001).

Apparent digestibility of $P$. The addition of exogenous dietary phytase increased hydrolysis of phytate $\mathrm{P}$ in lactating cows fed TMR containing either corn or barley (Table 9). The values for hydrolysis of phytate $P$ reflect the disappearance of phytate and not phytate $\mathrm{P}$ digestibility, i.e., the $\mathrm{P}$ hydrolyzed from phytate presumably was available for intestinal absorption but was not necessarily absorbed. Total $\mathrm{P}$ digestibility tended to be greater in diets with exogenous phytase. The level of exogenous phytase $(427 \mathrm{FTU} / \mathrm{kg}$ ) was selected based on the level that resulted in the highest apparent digestibility in feedlot cattle (Hurley et al., 2002). Total excretion of fecal $\mathrm{P}$ tended to be decreased in cows fed the diets with added phytase (Table 9). There was no significant difference in $\mathrm{P}$ digestibility or phytate $\mathrm{P}$ hydrolysis between the barley- and corn-based diets. Wu et al. (2000) reported diurnal variation in fecal $\mathrm{P}$ concentration. Based on the pattern of diurnal variation reported by Wu et al. (2000), collection of a single fecal sample at $0900 \mathrm{~h}$ would lead to overestimation of $\mathrm{P}$ digestibility. Thus, the relative $\mathrm{P}$ digestibility among treatments is representative of the diets, but the apparent digestibility values that are reported (Table 9) may be higher than actually occurred.

The concentration of $\mathrm{Ca}$ in the diet can affect phytase activity (Bedford, 2000) and ruminal phytate hydrolysis (Sansinena, 1999). Although Clark et al. (1986) observed higher apparent digestibility of $\mathrm{P}$ when the dietary Ca was $0.9 \%$ than when it was $0.6 \%$, others have found reduced $\mathrm{P}$ absorption with higher concentrations of dietary Ca (Field et al., 1983; Mathur, 1953). Barth and Hansard (1962) reported that phytate $\mathrm{P}$ utilization was $100 \%$ when Ca:P was $2: 1$, but fell to $67 \%$ when $\mathrm{Ca}: \mathrm{P}$ increased to $8: 1$. In the current experiment, $\mathrm{Ca}$ concentration ranged from 1.11 to $1.18 \%$ of the TMR (DM basis), and Ca:P in the TMR ranged from 2.4 to 2.6:1.

Fecal P, Ca, and phytate P. Fecal P excretion ( $\mathrm{g} /$ d) tended to be less in cows fed diets containing the added phytase (Table 9). The concentration of $\mathrm{P}$ in the feces averaged $0.59 \% \mathrm{DM}$ for cows fed the TMR containing barley diets and $0.55 \%$ for cows fed the TMR containing corn. Fecal excretion of phytate $\mathrm{P}(\mathrm{g} / \mathrm{d})$ was significantly less in cows given the phytase supplement. Fecal Ca was unaffected by either the added dietary phytase or the grain source fed to cows. The Ca concentration in feces of cows fed the barley, barley + phytase, corn, and corn + phytase diets were $2.5,2.4,2.6$, and $2.3 \%$, respectively.

\section{Comparison Between Experiments}

The lower $\mathrm{P}$ digestibilities in Experiment 1 compared with Experiment 2 probably were caused by a combina-

Table 9. Effect of grain source and added phytase on $\mathrm{P}$ intake, $\mathrm{P}$ secretion in milk, digestibility of total dietary $\mathrm{P}$, and phytate $\mathrm{P}$ in dairy cows (experiment 2 ).

\begin{tabular}{|c|c|c|c|c|c|c|c|c|}
\hline & \multicolumn{4}{|c|}{ Dietary treatment } & \multirow[b]{3}{*}{$\mathrm{SE}$} & \multirow{2}{*}{\multicolumn{3}{|c|}{$P<$}} \\
\hline & & Barley + & & Corn + & & & & \\
\hline & Barley & phytase $^{1}$ & Corn & phytase $^{2}$ & & Grain & Phytase & $\mathrm{G} \times \mathrm{P}^{3}$ \\
\hline Total P intake, g/d & 128 & 134.1 & 134 & 127.2 & 10.2 & 0.23 & 0.24 & 0.32 \\
\hline Phytate $\mathrm{P}$ intake, $\mathrm{g} / \mathrm{d}$ & 66.5 & 68.2 & 68.4 & 67.1 & 6.4 & 0.21 & 0.26 & 0.30 \\
\hline $\mathrm{P}$ in milk, $\mathrm{g} / \mathrm{d}$ & 39.9 & 39.0 & 39.1 & 38.7 & 2.5 & 0.57 & 0.32 & 0.72 \\
\hline $\mathrm{P}$ in feces, $\mathrm{g} / \mathrm{d}$ & 65.8 & 64.0 & 66.8 & 60.4 & 4.5 & 0.45 & 0.09 & 0.32 \\
\hline $\mathrm{P}$ absorbed, g/d & 62.2 & 70.0 & 67.1 & 66.8 & 3.1 & 0.13 & 0.11 & 0.27 \\
\hline $\mathrm{P}$ digestibility, $\%$ & 48.6 & 52.3 & 50.1 & 55.5 & 3.4 & 0.56 & 0.07 & 0.67 \\
\hline Phytate $P$ in feces, $g / d$ & 14.3 & 9.8 & 13.5 & 9.9 & 0.8 & 0.43 & 0.03 & 0.28 \\
\hline Phytate $\mathrm{P}$ hydrolysis, \% & 78.4 & 85.4 & 80.3 & 85.1 & 4.9 & 0.56 & 0.02 & 0.43 \\
\hline DM digestibility, \% & 68.5 & 67.5 & 68.0 & 66.8 & 3.3 & 0.38 & 0.22 & 0.38 \\
\hline
\end{tabular}

${ }^{1}$ Barley +427 FTU phytase/kg of DM. One FTU is the amount of enzyme that liberates $1 \mu \mathrm{mol}$ of phosphate/ min from $0.0051 \mathrm{~mol} / \mathrm{L}$ of $\mathrm{Na}$ phosphate at $37^{\circ} \mathrm{C}$ and $\mathrm{pH} 5.5$.

${ }^{2}$ Corn +427 FTU phytase/kg of DM.

${ }^{3} \mathrm{G} \times \mathrm{P}$ is the response caused by grain and phytase interaction. 


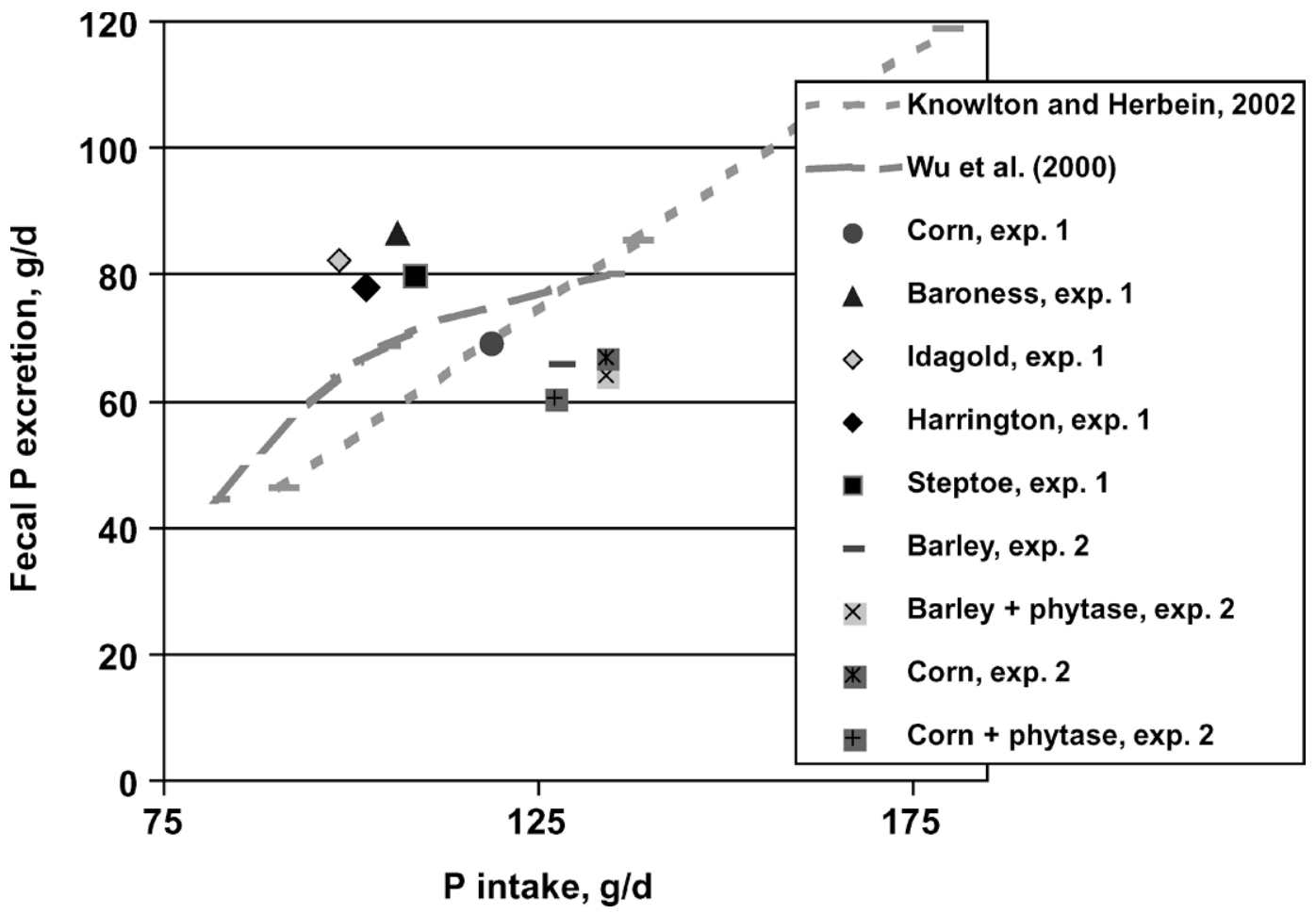

Figure 2. Comparison between $P$ intake $(\mathrm{g} / \mathrm{d})$ and fecal $\mathrm{P}$ excretion $(\mathrm{g} / \mathrm{d})$ of cows fed corn and barley diets in experiment 1 and cows fed diets containing corn or barley and added phytase in experiment 2; values are reported according to Knowlton and Herbein (2002) and Wu et al. (2000). Barley varieties in Experiment 1 are listed. Diets with added phytase contained 427 FTU phytase/kg of DM. One FTU is the amount of enzyme that liberates $1 \mu \mathrm{mol}$ of phosphate/min from $0.0051 \mathrm{~mol} / \mathrm{L}$ of $\mathrm{Na}$ phosphate at $37^{\circ} \mathrm{C}$ and $\mathrm{pH} 5.5$.

tion of factors. First, the TMR in experiment 1 had a higher percentage of $\mathrm{P}(0.55 \%$ vs. $0.46 \%)$, and $\mathrm{P}$ digestibility is known to decrease as the percentage of dietary $\mathrm{P}$ increases (Weiss and Wyatt, 2004). In addition, milk yields were much lower for cows in experiment 1 (20 vs. $43 \mathrm{~kg} / \mathrm{d}$ ); thus, less P was secreted into milk. Second, the diets in experiment 1 had higher NDF concentrations ( $40 \%$ vs. $35 \%$ ). Increased dietary NDF concentration enhance salivary flow, which increases total salivary $\mathrm{P}$ entering the rumen (Khorasani et al., 1997), and may reduce dietary $\mathrm{P}$ digestibility during $\mathrm{P}$ excess. Third, diets in experiment 2 contained wheat millrun, which possesses appreciable phytase activity (Cromwell, 1999). Thus, the endogenous phytase in what millrun might have hydrolyzed some phytate $\mathrm{P}$ in the diets in experiment 2. Accordingly, the lower $\mathrm{P}$ digestibilities in experiment 1 are to be expected.

Other differences between the 2 studies include the higher percentage of cereal grain in the diets of experiment $1(37.6 \%)$ vs. experiment $2(25.8 \%)$ and that $40 \%$ of the barley was ground in experiment 2 . Guyton et al. (2003) reported an interaction of ruminal starch availability and intake of phytic acid on ruminal phytase activity. In addition, the endogenous phytases in wheat millrun in experiment 2 might have hydrolyzed some of the phytate $\mathrm{P}$ in barley. In experiment 2 , grinding of $40 \%$ of the barley would have exposed more of the phytate to action of phytases, enhancing phytate hydrolysis. Finally, the higher percentage of $\mathrm{P}$ and NDF in diets of experiment 1 might have negatively affected $\mathrm{P}$ solubilization from barley.

When the P excretion data of both studies are compared with the $\mathrm{P}$ excretion data reported by Knowlton and Herbein (2002) and Wu et al. (2000), the P excretion for cows fed corn in experiment 1 agree with predicted values (Figure 2 ). Whereas cows fed the barley diets in experiment 1 excreted more $\mathrm{P}$ than predicted, cows in experiment 2 excreted less $\mathrm{P}$ than predicted. However, data in Figure 2 only represent $\mathrm{P}$ intake and fecal $\mathrm{P}$ excretion, ignoring milk $\mathrm{P}$ secretion. Also, the collection of a single fecal sample at $0900 \mathrm{~h}$ from cows in experiment 2 might have led to an underestimation of fecal $\mathrm{P}$ output. Thus, a combination of cow, diet, and sampling factors contributed to differences in estimates of $\mathrm{P}$ digestibility between the 2 experiments.

The added dietary phytase increased the hydrolysis of phytate $\mathrm{P}$ in lactating cows. In cows not fed supplemental phytase enzymes, hydrolysis of dietary phytate $\mathrm{P}$ ranged from 69 to $89 \%$. The phytate $\mathrm{P}$ hydrolysis in cows fed phytase ranged from 75 to $98 \%$. The results 
of the present experiment indicate that phytase supplementation tended to improve phytate $\mathrm{P}$ and total $\mathrm{P}$ digestibility in cattle fed either corn or barley as the grain source. The results are in contrast to a previous study where $>95 \%$ of phytate $\mathrm{P}$ hydrolysis occurred in the dairy cows without any addition of phytase (Clark et al., 1986). However, neither study separated the phytate hydrolysis that occurred in the rumen from that which occurred in the lower gastrointestinal tract. The current results are supported by the findings of Hurley et al. (2002) who reported higher P digestibility in feedlot cattle fed 500 FTU of phytase/kg of DM. Similarly, Sansinena (1999) found ruminal escape of phytate was 28 to $47 \%$, with greater escape occurring with increased dietary $\mathrm{Ca}(0.28$ to $1.75 \% \mathrm{Ca}, \mathrm{DM}$ basis). Another contributing factor to the improvement in $\mathrm{P}$ digestibility with added phytase in the current experiment is that the high-producing lactating cows had feed intakes of $4 \%$ of BW. Thus, the accompanying rapid rumen turnover rate may limit phytate hydrolysis prior to the absorption sites of $\mathrm{P}$ in the small intestine.

\section{CONCLUSIONS}

Differences exist in $\mathrm{P}$ digestibility among barley varieties, and in some situations, $\mathrm{P}$ digestibility of barley is less than that for corn. Addition of exogenous phytase to lactating cows fed corn or barley tended to improve $\mathrm{P}$ digestibility. Complete hydrolysis of phytate $\mathrm{P}$ does not always occur within the rumen, and in these situations, the addition of dietary phytase may enhance the amount of $\mathrm{P}$ that is available for absorption from the small intestinal tract. There was no effect of grain source or phytase supplementation on milk yield or composition.

\section{REFERENCES}

Association of Official Analytical Chemists. 1995. Official Methods of Analysis. Vol. 1. 16th ed. AOAC, Arlington, VA.

Association of Official Analytical Chemists. 2001. Official Methods of Analysis. 17th ed. AOAC, Arlington, VA.

Barth, J., and S. Hansard. 1962. Comparative availability of phytin and organic phosphorus to rumen microorganisms in vitro. Proc. Soc. Exp. Biol. Med. 109:448-454.

Bedford, M. R. 2000. Exogenous enzymes in monogastric nutritionTheir current value and future benefits. Anim. Feed Sci. Technol. 86:1-13.

Bergman, E. L., K. Autio, and A. S. Sandberg. 2000. Optimal conditions for phytate degradation, estimation of phytase activity, and localization of phytate in barley. J. Agric. Food Chem. 48:4647-4655.

Bravo, D., F. Meschy, C. Bogaert, and D. Sauvant. 2000. Ruminal phosphorus availability from several feedstuffs measured by the nylon bag technique. Reprod. Nutr. Dev. 40:149-162.

Casper, D. P., and D. J. Schingoethe. 1989. Lactational response of dairy cows to diets varying in ruminal solubilities of carbohydrate and crude protein. J. Dairy Sci. 72:928-941.

Clark, W. D., Jr., J. E. Wohlt, R. L. Gilbreath, and P. K. Zajac. 1986. Phytate phosphorus intake and disappearance in the gastrointes- tinal tract of high producing dairy cows. J. Dairy Sci. 69:31513155 .

Cromwell, G. L. 1999. Bioavailability of calcium and phosphorus in plant and animal ingredients. Pages 173-190 in Phytase in Animal Nutrition and Waste Mangement-A BASF Reference Manual. M. B. Coelho and E. T. Kornegay, ed. BASF Corp., Mount Olive, NJ.

Eeckhout, W., and M. de Paepe. 1994. Total phosphorus, phytatephosphorus and phytase activity in plant feedstuffs. Anim. Feed Sci. Technol. 47:19-29.

Environmental Protection Agency. 2002. Concentrated Animal Feeding Operations Ruling. Available: http://www.epa.gov/npdes/ caforule. Accessed June 15, 2003.

Field, A. C., J. Kamphues, and J. A. Williams. 1983. The effect of dietary intake of calcium and phosphorus on the absorption and metabolism of phosphorus in sheep. J. Agric. Sci. 101:597-602.

Forar, F. L., R. L. Kincaid, R. L. Preston, and J. K. Hillers. 1982. Variation of inorganic phosphorus in blood plasma and milk of lactating cows. J. Dairy Sci. 65:760-763.

Guyton, A. D., J. M. McKinney, and K. F. Knowlton. 2003. The effect of steam-flaked or dry ground corn and supplemental phytic acid on phosphorus partitioning and ruminal phytase activity in lactating cows. J. Dairy Sci. 86:3972-3982.

Hurley, L. A., T. L. Stanton, M. J. Jarosz, and D. Schutz. 2002. Effects of dietary phosphorus and microbial phytase level of beef finishing performance. Prof. Anim. Sci. 18:286-292.

Khorasani, G. R., R. A. Janzen, W. B. McGill, and J. J. Kennelly. 1997. Site and extent of mineral absorption in lactating cows fed whole-crop cereal grain silage or alfalfa silage. J. Anim. Sci. 75:239-248.

Kincaid, R., and J. Harrison. 2002. Feeding barley to dairy cattle may have advantages. Feedstuffs 74(2):33-40.

Knowlton, K. F., and J. H. Herbein. 2002. Phosphorus partitioning during early lactation in dairy cows fed diets varying in phosphorus content. J. Dairy Sci. 85:1227-1236.

Lynch, P. B., and P. J. Caffrey. 1997. Phosphorus requirements for animal production. In Phosphorus Loss from Soil Water. H. Tunney, O. T. Carton, P. C. Brookes, and A. E. Johnston, ed. CAB International, Wallingford, UK.

Mathur, M. L. 1953. Assimilation of phytin phosphorus by dairy cows. Ind. J. Anim. Sci. 23:243-248.

McCarthy, R. D., Jr., T. H. Klusmeyer, J. I. Vicini, J. H. Clark, and D. R. Nelson. 1989. Effects of source of protein and carbohydrate on ruminal fermentation and passage of nutrients to the small intestine of lactating cows. J. Dairy Sci. 72:2002-2016.

National Research Council. 2001. Nutrient Requirements of Dairy Cattle. Natl. Acad. Sci., Washington, DC.

O’Dell, B. L., A. R. de Boland, and S. R. Koirtyohann. 1972. Distribution and nutritionally important elements among the morphological components of cereal grains. J. Agric. Food Chem. 20:718-721.

Raboy, V., D. B. Dickinson, and F. E. Below. 1984. Variation in seed total phosphorus, phytic acid, zinc, calcium, magnesium, and protein among lines of Glycine max and G. soja. Crop Sci. 24:431-434.

Ravindran, V. 1999. Occurrence of phytic acid in plant feed ingredients. Pages 85-92 in Phytase in Animal Nutrition and Waste Management-A BASF Reference Manual. M. B. Coelho and E. T. Kornegay (eds.). BASF Corp., Mount Olive, NJ.

Read, M. V. P., E. A. N. Engels, and W. A. Smith. 1986. Phosphorus and the grazing ruminant. 4. Blood and fecal grab samples as indicators of $\mathrm{P}$ status of cattle. S. Afr. J. Anim. Sci. 16:18-22.

Reddy, N. R., S. K. Sathe, and D. K. Salunkhe. 1982. Phytases in legumes and cereals. Adv. Food Res. 28:1-92.

Robinson, J. W. 1975. Atomic Absorption Spectroscopy, 2nd ed. Marcel Dekker, Inc., New York, NY.

SAS. 2001. User's Guide, Version 8.1, 1st ed. SAS Inst. Inc., Cary, NC. Sansinena, M. J. 1999. Phytate phosphorus metabolism in Holstein calves. M. S. Thesis. Louisiana State University, Baton Rouge.

Tamminga, S., A. M. van Vuuren, C. J. van der Koelen, R. S. Ketelaar, and P. L. van der Togt. 1990. Ruminal behavior of structural carbohydrates, non-structural carbohydrates, and crude protein 
from concentrate ingredients in dairy cows. J. Agric. Sci. 128:331-337.

Taylor, N., G. P. Bowman, K. A. Anderson, L. M. M. Surber, T. K. Blake, V. Raboy, J. A. Dorsch, and J. G. Broyles. 2001. Phytic acid levels in barley for beef cattle. Proc. West. Sec. Amer. Soc. Anim. Sci. 52:492-495.

Tronier, B., R. L. Ory, and K. W. Henningsen. 1971. Characterization of the fine structure and proteins from barley protein bodies. Phytochemistry 10:1207-1311.

Valk, H., J. A. Metcalf, and P. J. A. Withers. 2000. Prospects for minimizing phosphorus excretion in ruminants by dietary manipulation. J. Environ. Qual. 29:28-36.
Weiss, W. P., and D. J. Wyatt. 2004. Macromineral digestion by lactating dairy cows: Estimating phosphorus excretion via manure. J. Dairy Sci. 87:2158-2166.

Wu, Z., L. D. Satter, and R. Sojo. 2000. Milk production, reproductive performance, and fecal excretion of phosphorus by dairy cows fed three amounts of phosphorus. J. Dairy Sci. 83:1028-1041.

Yang, W. Z., K. A. Beauchemin, B. I. Farr, and L. M. Rode. 1997. Comparison of barley, hull-less barley, and corn in the concentrate of dairy cows. J. Dairy Sci. 80:2885-2895.

Yanke, L. J., H. D. Bae, L. B. Selinger, and K.-J. Cheng. 1998. Phytase activity of anaerobic ruminal bacteria. Microbiology 144:15651573. 